\title{
Perbandingan Metode Latihan Interval Ekstensif dan Intensif Terhadap Peningkatan Daya Tahan Aerobik
}

\section{Comparison of Extensive And Intensive Interval Exercise Methods to Increasing Aerobic Endurance}

\author{
Mochamad Zakky Mubarok', Yudhi Kharisma² \\ 1,2 Program Studi Pendidikan Jasmani Kesehatan dan Rekreasi, STKIP Nahdlatul Ulama \\ Indramayu \\ email: m.zakky@stkipnu.ac.id¹ ,yudhi_kharisma@stkipnu.ac.id²
}

: https://doi.org/10.20884/1.paju.2020.3.1.4813

\begin{abstract}
Abstrak
Daya tahan aerobik merupakan pondasi kemampuan fisik seseorang. Metode latihan yang tepat sangat dibutuhkan dalam peningkatan kondisi fisik khususnya daya tahan aerobik sebagai upaya pembinaan dan proses pelatihan. Tujuan dalam penelitian ini adalah membandingkan penerapan metode latihan interval yang ekstensif dan metode latihan interval yang intensif dalam meningkatkan daya tahan aerobik. Penelitian ini menggunakan metode penelitian eksperimen dengan desain penelitian menggunakan nonequivalent control grup design. Instrumen yang digunakan untuk mengetahui daya tahan aerobik mengunakan Tes Multi Tahap (Bleep Test). Subjek yang dijadikan partisipan dalam penelitian ini adalah 30 mahasiswa dari salah satu program studi Pendidikan Jasmani Kesehatan dan Rekreasi yang berada di wilayah 3 Jawa Barat dengan menggunakan teknik purposive sampling. Hasil penelitian menyatakan bahwa: (1) Metode latihan interval yang ekstensif memberikan pengaruh terhadap peningkatan daya tahan aerobik. (2) Metode latihan interval yang intensif memberikan pengaruh terhadap peningkatan daya tahan aerobik. (3) Metode Latihan interval yang intensif memberikan pengaruh yang lebih baik dibandingkan dengan metode latihan interval yang ekstensif terhadap peningkatan daya tahan aerobik Kesimpulannya bahwa metode latihan interval yang intensif lebih baik dalam meningkatan daya tahan aerobik dibandingkan metode latihan interval yang ekstensif.
\end{abstract}

Kata kunci: Daya Tahan Aerobik, Ekstensif; Intensif; Interval

\begin{abstract}
Aerobic endurance is a person's physical ability. Appropriate exercise methods are needed in improving physical conditions, especially aerobic endurance as an effort to develop and train the process. The purpose of this study is the application of extensive interval training methods and intensive interval training
\end{abstract}

Alamat Koresponden: Program Studi Pendidikan Jasmani Kesehatan dan Rekreasi, STKIP Nahdlatul Ulama Indramayu

Email:m.zakky@stkipnu.ac.id (c) (i) 
methods in increasing aerobic endurance. This research uses experimental research method with research design using nonequivalent control group design. The instrument used to determine aerobic endurance is a Multi-Stage Test (Bleep Test). The subjects who participated in this study were 30 students from one of the Health and Recreation Physical Education study programs in Region 3 West Java using purposive sampling technique. The results of the study stated that: (1) Extensive interval training methods had an effect on increasing aerobic endurance. (2) Interval training method that has an effect on increasing aerobic endurance. (3) The interval training method that gives a better effect than the extensive interval training method on increasing aerobic endurance concludes that the intensive interval training method is better than the extensive interval training method.

Keywords: Aerobic Endurance, Extensive; Intensive; Interval

\section{PENDAHULUAN}

Kemampuan kondisi fisik memegang peranan yang sangat penting dalam olahraga prestasi. Penyusunan program latihan terutama aspek latihan fisik perlu direncanakan secara baik dan sistematis yang bertujuan untuk meningkatkan kemampuan kesegaran jasmani dan kemampuan fungsional tubuh dalam menunjuang pencapaian prestasi maksimal. Kemampuan kondisi fisik merupakan unsur yang sangat penting dan menjadi fondasi dalam mengembangkan dan meningkatkan kemampuan teknik, penerapan taktik dan strategi serta mental atlet (Mubarok \& Mudzakir, 2020)

Latihan kondisi fisik merupakan sebuah latihan fisiologis yang sistemik, dilakukan secara sistematis, berulang dan progresif ditingkatkan untuk meningkatkan efisiensi kerja dan memelihara kondisi tubuh. Program latihan harus mengikuti periodesasi yang sudah disusun dan direncanakan berdasakan cabang olahraga, sehingga sistem energi dan otot atlet dapat beradaptasi dengan kekhususan cabang olahraga. Latihan merupakan sebuah kegiatan yang sistematis dilakukan secara berulang-ulang dengan beban latihan kian bertambah (progresif) yang memiliki tujuan akhir untuk memperbaiki kemampuan gerak dengan cara mengorganisasikan sistem latihan dengan baik guna meningkatkan prestasi olahraga (Mubarok, 2021).

Daya tahan aerobik merupakan komponen kemampuan fisik yang sangat penting untuk ditingkatkan demi menunjang peningkatan aspek latihan yang lain. (Giriwijoyo \& Sidik, 2012) menjelaskan hakikat latihan fisik merupakan pelatihan untuk meningkatkan batas kemampuan makasimal atlet, dengan kemampuan aerobik yang tinggi disamping 
Mochamad Zakky Mubarok \& Yudhi Kharisma| Perbandingan Metode Latihan Interval Ekstensif dan Intensif Terhadap Peningkatan Daya Tahan Aerobik

menunda datangnya kelelahan juga mampu mempercepat pemulihan, baik pemulihan secara parsial (on court) maupun pemulihan secara total (out of court).

Sebuah latihan yang bervariatif akan menumbuhkan semangat atlet dalam mengikuti setiap sesi latihan, maka dari itu diperlukan sebuah metode latihan yang digunakan untuk menghindari latihan yang monoton dan membosankan sehingga kurang menarik bagi atlet. Metode yang akan digunakan dalam penelitian ini adalah metode latihan interval. Pelaksanaan metode latihan interval adalah konsistensi dalam norma pembebanan, jarak yang ditempuh konsisten, usaha (intensitas) yang dilakukn konsisten, dan yang paling penting adalah masa istirahat yang dilakukan antar pengulangan berlangsung secara konsisten (Sidik, 2011).

Metode latihan interval secara pelaksanaan bertujuan untuk mengembangkan dan meningkatkan daya tahan aerobik. Latihan interval sangat dianjurkan karena memang hasilnya sangat positif bagi perkembangan daya tahan atlet, latihan interval sendiri merupakan suatu sistem latihan yang diselingi oleh interval-interval yang berupa masa istirahat (Mulyawan et al., 2016).

Metode latihan interval mempunyai karakteristik yaitu konsistensi dalam usaha yang dilakukan dan masa istirahat yang dilakukan antar pengulangan berlangsung secara konsisten. Pelaksanaan metode latihan interval yang harus diperhatikan adalah perlunya diketahui denyut nadi atlet untuk pemulihan setelah kerja/aktivitas (repetisi) pertama. Hasil denyut nadi yang diketahui diawal akan menjadi patokan untuk digunakan sebagai waktu istirahat pada pengulangan berikutnya, dan ketahui kembali waktu pemulihan setelah berakhir repetisi pada set pertama yang kemudian dijadikan patokan untuk istirahat antar set (Mubarok, 2019).

Pelaksanaan metode latihan interval dibagi menjadi latihan interval yang ekstensif dan latihan interval yang intensif. Metode latihan interval yang ekstensif dalam penerapannya dilakukan dengan cara intensitas latihan rendah-sedang, dengan denyut nadi sekitar 170x/ menit atau lebih rendah, repetisi latihan banyak, intervalnya dilakukan dengan singkat dan diberikan dengan jumlah set atau seri yang banyak, jarak latihan sampai 800 meter, 100 meter, 1200 meter. Sedangkan metode latihan interval yang intensif dalam penerapannya dilakukan dengan intensitas latihan sedang-tinggi, dengan denyut nadi diatas $170 \mathrm{x} /$ menit, repetisi latihan yang diberikan tidak banyak, interval yang dilakukan lebih lama dan diberikan dengan jumlah maksimal 3 set (Sidik et al., 2019). 
Metode latihan interval dapat meningkatkan kemampuan kinerja fisik, bentuk pelatihan ini bertujuan untuk memperbaiki indikator kapasitas fisik seperti pengangkatan laktat dari darah, penyerapan oksigen maksimal dan kemampuan aerobik maksimal. Dengan demikian, pelatihan semacam ini dapat digunakan untuk meningkatkan kemampuan kapasitas aerobik dan anaerobik seseorang (Hebisz et al., 2016).

Daya tahan aerobik atau sering disebut kemampuan VO2Max adalah volume maksimal 02 yang diproses oleh tubuh manusia pada saat melakukan kegiatan yang intensif. VO2Max ini adalah suatu tingkatan kemampuan tubuh yang dinyatakan dalam liter per menit atau milliliter/menit/kg berat badan. Tinggi rendahnya daya tahan aerobik seseorang berhubungan dengan kemampuan beraktivitas seseorang. Semakin tinggi kemampuan daya tahan aerobik seseorang, maka tingkat aktivitasnya semakin tinggi dan tingkat kelelahannya semakin rendah. Daya tahan aerobik yang sering dikenal dengan VO2Max adalah jumlah oksigen yang digunakan oleh otot selama interval tertentu untuk metabolisme sel dan memproduksi energi. VO2Max dijadikan sebagai indikator dari basarnya kapasitas sintesis cadangan energi aerobik seseorang (Kharisma \& Mubarok, 2020)

Kadar kemampuan daya tahan aerobik, berhubungan dengan kemampuan kerja otot seseorang. Jika seseorang melakukan kerja, makin berat kerja yang dilakukan, makin tinggi konsumsi oksigennya. Semakin tinggi daya tahan aerobik, maka semakin lama kemampuan otot melakukan kerja artinya otot tidak cepat lelah. Sebaliknya semakin rendah kemampuan daya tahan aerobik, maka semakin cepat kemampuan otot melakukan kerja, sehingga otot menjadi cepat lelah. Kemampuan daya tahan aerobik adalah tingkat dimana seseorang dapat mengambil dan mengkonsumsi oksigen dari atmosfer untuk aerobik respirasi dan index ketahanan oksigen secara maksimal dibatasi dengan jumlah oksigen yang dihubungkan ke otot (Harsono, 2017).

Penerapan metode latihan interval yang intensif diduga akan lebih efektif dan efisien untuk meningkatkan kemampuan daya tahan aerobik dibandingkan metode latihan yang ekstensif karena mempunyai perhatian khusus dalam intensitas maupun pada masa pemulihan (istirahat). Latihan dengan metode interval yang dilakukan secara berlanjut dengan intensitas yang tinggi memberikan efek yang signifikan terhadap peningkatan kardiovascular, parameter pernapasan dan parameter darah. Pelatihan olahraga apapun 
Mochamad Zakky Mubarok \& Yudhi Kharisma| Perbandingan Metode Latihan Interval Ekstensif dan Intensif Terhadap Peningkatan Daya Tahan Aerobik

bentuknya apabila intensitasnya adekuat dan dilakukan secara intensif akan membantu meningkatkan keterampilan menjadi lebih baik (Mubarok \& Ramadhan, 2019).

Permasalahan yang sering terjadi dilapangan, masih banyak pelatih kurang memahami pelaksanaan sebuah metode latihan yang sesuai dan dibutuhkan dalam proses meningkatkan kemampuan daya tahan aerobik, kekeliruan dalam penerapan metode latihan interval yang ektensif dan interval yang intensif masih sering terjadi, sehingga dampak latihan yang telah dilakukan menjadi tidak maksimal. Memiliki kemampuan daya tahan aerobik yang baik, merupakan sebuah pondasi dalam menunjang pencapaian sebuah prestasi yang terkadang kurang mendapatkan perhatian dari pelatihnya dalam penyusunan program latihan. Tujuan dari penelitian ini yaitu untuk mengetahui seberapa besar pengaruh metode latihan interval yang ekstensif dan metode latihan interval yang intensif terhadap peningkatan daya tahan aerobik. Serta membandingkan mana yang lebih baik dalam memberikan peningkatan daya tahan aerobik antara metode latihan interval yang ekstensif dengan metode interval yang intensif.

\section{METODE}

Metode penelitian yang digunakan adalah metode eksperimen. Dijelaskan Penelitian eksperimen adalah hanya jenis penelitian yang langsung berusaha untuk mempengaruhi variabel utama, dan jenis penelitian yang benar-benar dapat menguji hipotesis tentang hubungan sebab dan akibat (Arikunto, 2013). Tujuan penelitian dari ini adalah melihat hubungan antara variabel yang diteliti dengan melakukan pengamatan dan kontrol yang cermat. Variabel bebas dalam penelitian ini yaitu metode latihan interval yang ekstensif dan metode latihan interval yang intensif, sedangkan variabel terikat yaitu kemampuan daya tahan aerobik (VO2Max).

Desain penelitian yang digunakan dalam penelitian ini adalah Nonequivalent Control Group Design. Desain penelitian ini hampir sama dengan pretest-posttest control group design, bedanya pada desain ini kelompok eksperimen maupun kelompok kontrol tidak dipilih secara random (Sugiyono, 2019).

Teknik pengambilan sampel dalam penelitian ini menggunakan purposive sampling. Teknik purposive sampling merupakan pengambilan sampel dengan pertimbangan tertentu atau menentukan sampel penelitian dengan tujuan tertentu (Ginanjar, 2019). Partisipan yang digunakan dalam penelitian ini berjumlah 30 orang mahasiswa dari program studi 
Pendidikan Jasmani Kesehatan dan Rekreasi STKIP Nahdlatul Ulama Indramayu. Peneliti menentukan ciri-ciri partisipan yang digunakan yaitu: merupakan mahasiswa aktif mengikuti perkuliahan serta berusia 17 sampai 19 tahun serta mahasiswa tersebut memiliki kemampuan daya tahan aerobik yang baik. Untuk pembagian sampel dalam kelompok penelitian, peneliti memberikan nomor urutan dari nomor 1 sampai 30, Nomor urut ganjil 1,3,5 sampai 29 sebagai kelas kontrol yang berjumlah 15 orang, sedangkan nomor urut genap dari mulai 2,4,6 sampai 30 merupakan kelas eksperimen dengan keseluruhan sampel kelompok kontrol dan eksperimen berjumlah 15 mahasiswa.

Instrumen yang dipakai untuk mengetahui kemampuan daya tahan aerobik mengunakan Tes Multi Tahap (Bleep Test) yang bersumber dari (Nurhasan \& Cholil, 2012). Teknik analisis data menggunakan paired samples $t$ test dan independent $t$ test menggunakan IBM SPSS 24.

\section{HASIL}

Berdasarkan hasil analisis data dilapangan hasilnya metode latihan interval yang ekstensif dan metode latihan yang intensif berhasil meningkatkan kemampuan daya tahan aerobik. Dengan hasil yang didapat (df) $n-1=15$ pada taraf signifikansi 0.05 , didapat $t$ sebesar 6.73 dengan P-value $<0.05(0.00<0.05)$, maka latihan interval yang ekstensif memberikan pengaruh terhadap peningkatan kemampuan daya tahan aerobik. Selanjutnya dengan hasil (df) $n-1=15$ pada taraf signifikansi 0.05 , didapat t sebesar 7.84 dengan $P$ value $<0.05(0.00<0.05)$, latihan metode interval yang intensif memberikan pengaruh terhadap peningkatan kemampuan daya tahan aerobik. Rekapitulasi hasil data lebih jelas dapat dilihat pada Tabel 1 berikut:

Tabel 1. Hasil Penghitungan Paired Samples T Test

\begin{tabular}{ccc}
\hline Metode Interval Ekstensif & Metode Interval Intensif & Keterangan \\
\hline 6.73 & 7.84 & $\mathrm{t}$ \\
\hline 0.00 & 0.00 & Asym. Sig (P-value) \\
\hline $\mathrm{P}<0.05$ & $\mathrm{P}<0.05$ & Kondisi \\
\hline
\end{tabular}

Sedangkan hasil yang didapatkan dari perbandingan antara metode latihan yang ekstensif dan metode latihan yang intensif, (df) $n-2=30$ pada taraf signifikansi sebesar 0.05 , hasilnya didapat t sebesar 3.47 dengan P-value $<0.05(0.03<0.05)$ maka metode 
Mochamad Zakky Mubarok \& Yudhi Kharisma| Perbandingan Metode Latihan Interval Ekstensif dan Intensif Terhadap Peningkatan Daya Tahan Aerobik

latihan interval yang intesif memberikan pengaruh yang lebih baik dan signifikan dibandingkan dengan metode latihan interval yang ekstensif terhadap peningkatan kemampuan daya tahan. Rekapitulasi hasil penghitungan dapat dilihat pada tabel 2 , berikut ini:

Tabel 2. Hasil Perhitungan Independent Samples T test

\begin{tabular}{cc}
\hline $\begin{array}{c}\text { Metode Interval Ekstensif } \\
\text { Metode Interval Intensif }\end{array}$ & Keterangan \\
\hline 3.47 & $\mathrm{~T}$ \\
\hline 0.03 & Asym. Sig (P-value) \\
\hline $\mathrm{P}<0.05$ & Kondisi \\
\hline
\end{tabular}

Berdasarkan hasil penelitian dilapangan yang didukung penemuan penelitian, hasilnya terdapat perbedaan rata-rata peningkatan kemampuan daya tahan aerobik mahasiswa dari program studi Pendidikan Jasmani Kesehatan dan Rekreasi STKIP Nahdlatul Ulama Indramay sebelum dan sesudah diberikan treatment melalui metode latihan interval yang ekstensif dan metode latihan interval yang intensif.

\section{PEMBAHASAN}

Penerapan latihan melalui metode latihan interval yang ekstensif yang pelaksaannya dilakukan dengan intensitas rendah-sedang, denyut nadi dibawah 170x/menit, repetisi banyak, intervalnya singkat dan set/seri yang banyak menunjukkan memberikan pengaruh yang baik untuk peningkatan kemampuan daya tahan aerobik. Sejalan dengan penelitian (Elamaran, 2014) bahwa latihan daya tahan aerobik yang dilakukan dengan intensitas rendah, mengembangkan kapasitas aerobik dengan pemanfaatan lemak otot dan meningkatkan kepadatan pembuluh darah kapiler, bersama dengan peningkatan kemamampuan daya tahan aerobik, serta membantu meningkatkan kapasitas oksidatif otot.

Pemberian pelatihan dengan menggunakan metode latihan interval yang ekstensif menunjukkan keunggulan dalam peningkatan kemampuan daya tahan aerobik. Dijelaskan (Harsono, 2018) bahwa metode latihan dengan kegiatan yang berupa pengulangan yang berkali-kali supaya asosiasi stimulus dan respon menjadi sangat kuat dan tidak mudah 
untuk dilupakan. Hal ini mendukung hasil penelitian (Yamin \& Gusril, 2020) yang menyatakan penerapan latihan interval ekstensif dengan banyaknya pengulangan dan istirahat yang sedikit akan memberikan rangsangan terhadap kerja jantung sehingga proses pengambilan oksigen akan maksimal.

Grafik peningkatan dari kelompok mahasiswa yang diberikan treatment melalui penerapan metode latihan interval yang ekstensif dari mulai hasil tes awal, tes akhir dan gain skor dapat dilihat pada gambar 1 .

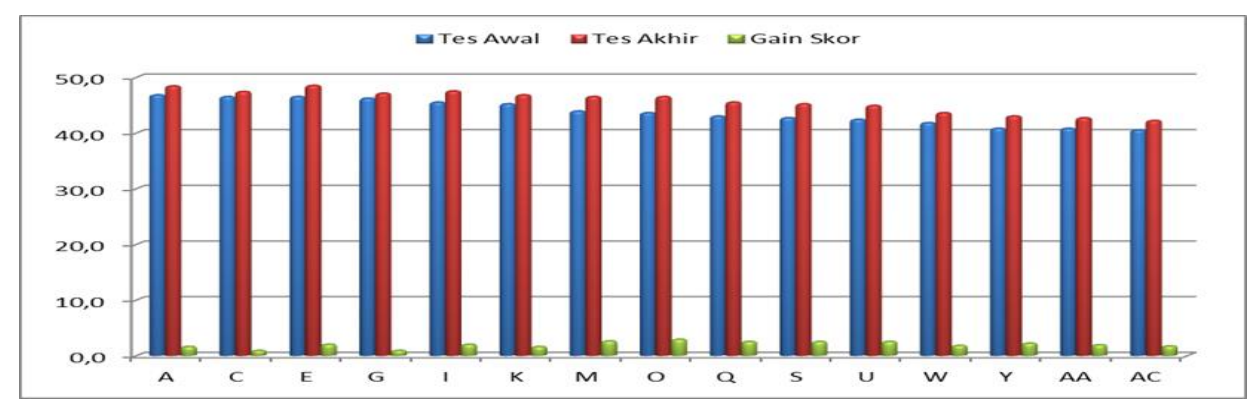

Gambar 1. Hasil Perbedaan Peningkatan Melalui Latihan Interval Ekstensif

Penerapan melalui metode interval yang intensif dengan program latihan intensitas latihan sedang-tinggi dengan denyut nadi lebih dari 180-190x/menit, repetisi sedikit, interval tidak banyak maksimal 3 set dengan pengaturan waktu istirahat di antara repetisi dan di antara set, menunjukkan pengaruh yang lebih baik dalam meningkatkan kemampuan daya tahan aerobik. Sejalan dengan hasil penelitian (Suhdy, 2018) bahwa metode interval intensif ini akan mampu meningkatkan saraf-saraf motorik yang komplek. Istirahat yang tidak penuh ini dapat dilakukan dengan istirahat pasif yaitu istirahat tanpa melakukan aktifitas (tidur, berdiri, duduk) dan dalam bentuk istrahat aktif yaitu istirahat dengan melakukan aktifitas yang ringan (lari kecil, jalan). Selanjutnya penelitian (Alkayis \& Soedjatmiko, 2019) yang menyatakan bahwa latihan interval intensif berpengaruh dalam meningkatkan kemampuan VO2max. Grafik rata-rata peningkatan kemampuan daya tahan aerobik melalui metode latihan interval yang intensif dapat terlihat pada gambar 2.

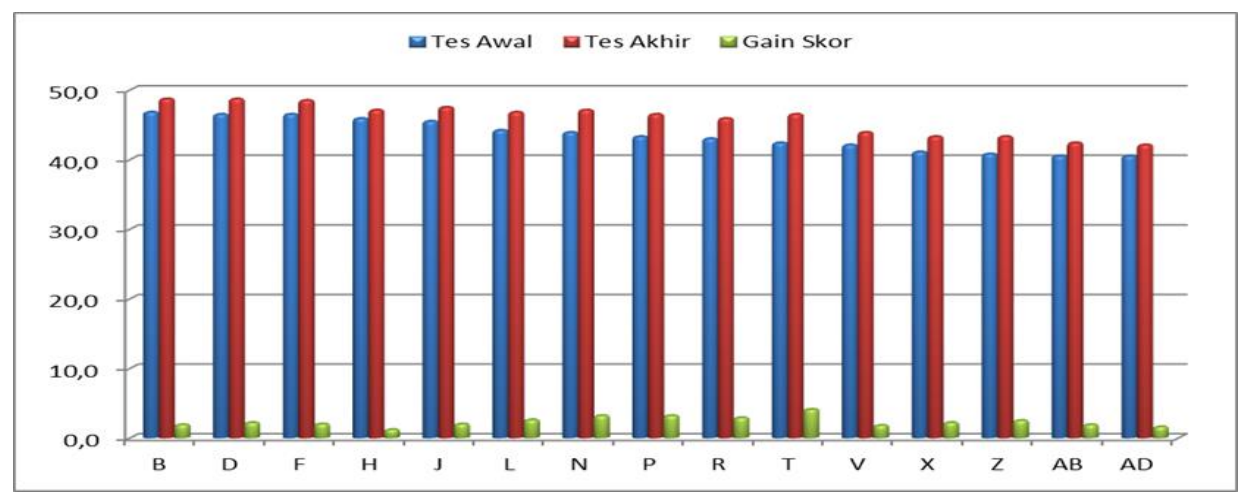


Mochamad Zakky Mubarok \& Yudhi Kharisma| Perbandingan Metode Latihan Interval Ekstensif dan Intensif Terhadap Peningkatan Daya Tahan Aerobik

Gambar 2. Hasil Perbedaan Peningkatan Melalui Latihan Interval Intensif

Metode latihan interval yang intensif memberikan pengembangan terhadap kemampuan daya tahan aerobik. Latihan kondisi fisik memiliki peran yang sangat penting dalam meningkatkan dan mempertahankan kemampuan fisik, semakin tinggi kemampuan fisik maka menentukan kemampuan kapasitas aerobik. Melalui metode latihan dengan intensitas yang tinggi, pengulangan yang sedikit dan waktu istirahat yang singkat dapat meningkatkan Kapasitas aerobik maksimum yang mana sering disebut VO2Max yang tergolong salah satu faktor fisik dalam menentukan prestasi (Karimah et al., 2019). Hal ini mendukung hasil penelitian (Chéilleachair et al., 2016) yang menyatakan delapan minggu penerapan high-intensity interval training (HIIT) yang dilakukan sangat efektif dalam meningkatkan kinerja dan karakteristik aerobik atlet.

Berdasarkan grafik hasil peningkatan rata-rata gain skor kedua kelompok, terdapat perbedaan dalam meningkatkan kemampuan daya tahan aerobik. Kelompok yang diberikan treatment metode latihan interval yang ekstensif terdapat gain skor sebesar 2,1. Sedangkan kelompok yang diberikan treatment metode latihan interval yang intensif terdapat gain skor sebesar 2,6. Berikut ini, gambaran peningkatan rata-rata kedua kelompok mahasiswa yang diberikan treatment dengan metode latihan interval yang ekstensif dan kelompok metode latihan interval yang intensif.

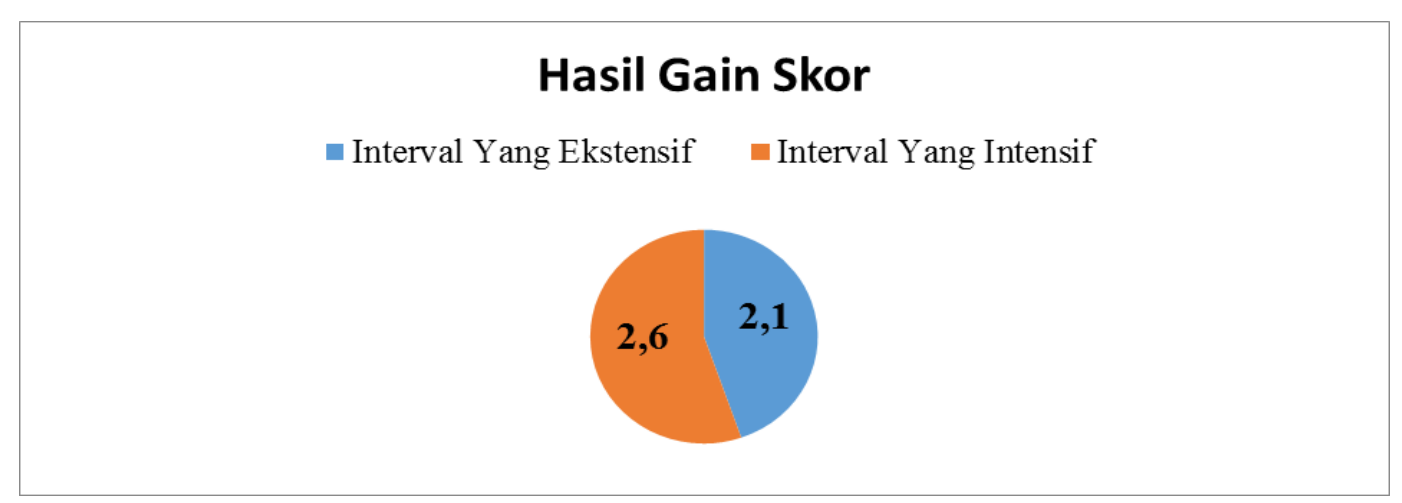

Gambar 3. Hasil Perbedaan Rerata Gain Skor Kedua Kelompok

Pelaksaanaan kedua metode latihan interval tersebut, perbedaan yang paling utama antara penerapan metode latihan interval yang ekstensif dan metode latihan intensif yaitu intensitas latihan. Metode latihan interval yang ekstensif penerapan intensitas latihan rendah-sedang sekitar $\leq 85 \%$, dengan denyut nadi sekitar 170x/ menit atau lebih rendah. Sedangkan penerapan metode latihan interval yang intensif dilakukan dengan intensitas latihan sedang-tinggi sekitar, dengan denyut nadi diatas 180-190x/menit. 
Dari perbedaan intensitas latihan dari kedua kelompok tersebut, metode latihan interval yang intensif memberikan pengaruh yang lebih besar dibandingkan dengan metode latihan yang eksensif. Selain dari itu kesiapan sampel, psikologi sampel, perbedaan kecemasan (anxiety), kesiapan menghadapi tekanan latihan serta terbatasnya waktu penelitian bisa menjadi faktor lain penyebab penerapan metode latihan interval yang intensif menjadi lebih baik memberikan pengaruh terhadap peningkatan kemampuan daya tahan aerobik dibandingkan dengan metode latihan interval yang ekstensif. Hal ini mendukung hasil penelitian (Rosdiana et al., 2019) yang menyatakan bahwa high intensity interval training juga bisa disebut sprint interval training (SIT) yang dijalankan dan dilakukan dengan tinggi intensitas mulai dari yang paling rendah $85 \%$ dapat meningkatkan kapasitas VO2Max sebesar 250\%. Selanjutnya hasil penelitian (Sari et al., 2019) yang menjelaskan bahwa pelatihan high intensity interval training memiliki pengaruh yang signifikan terhadap peningkatan kemampuan daya tahan aerobik pemain futsal putri.

Berdasarkan fakta dilapangan dan analisis data serta didukung penelitian yang relevan, peneliti menemukan bahwa melalui penerapan metode latihan interval yang intensif sangat baik dalam mendukung dalam proses latihan untuk meningkatkan kemampuan daya tahan aerobik, karena metode latihan ini berdampak positif dan memberikan peningkatan kapasitas daya tahan aerobik (VO2Max) yang nantinya mendukung ke aspek latihan yang lainnya.

\section{SIMPULAN}

Berdasarkan hasil dari pengolahan dan analisis data serta pengujian hipotesis yang telah dilakukan maka dapat disimpulkan bahawa metode latihan interval yang ekstensif dan metode interval yang intensif memberikan pengaruh terhadap peningkatan kemampuan daya tahan aerobik. Dari kedua metode latihan tersebut, yang memberikan pengaruh lebih baik terhadap peningkatan kemampuan daya tahan aerobik adalah metode latihan interval yang intensif.

Hasil penelitian ini dapat membantu dan menjadi acuan secara khusus untuk para pelatih serta pembaca pada umumnya, bahwa dalam penerapan latihan dibutuhkan metode latihan yang tepat dan diberikan secara sistematis dengan kesesuaian dengan prinsip latihan, bahwa penerapan metode latihan interval yang intensif merupakan sebuah metode latihan yang tepat dan efektif dalam meningkatkan kemampuan daya tahan aerobik. 
Mochamad Zakky Mubarok \& Yudhi Kharisma| Perbandingan Metode Latihan Interval Ekstensif dan Intensif Terhadap Peningkatan Daya Tahan Aerobik

Bagi peneliti kedepannya, diharapkan untuk dapat mencari lagi metode latihan yang tepat dalam upaya meningkatkan kemampuan daya tahan aerobik (VO2Max), sehingga pengetahuan dalam proses peningkatan kondisi fisik menjadi semakin banyak

\section{UCAPAN TERIMA KASIH}

Terima kasih kepada Kemenristek Dikti yang telah mendanai penelitian ini, melalui Hibah Penelitian Dosen Pemula tahun pelaksanaan 2021.

\section{DAFTAR PUSTAKA}

Alkayis, M., \& Soedjatmiko. (2019). Perbedaan Pengaruh Latihan Interval Ekstensif Dan Intensif Terhadap Vo2max (Eksperimen Pada Peserta Ekstrakulikuler Futsal SMA Negeri 1 Slawi Tahun 2019). Jurnal of Sport Coaching and Physical Education, 4(2), 95-103. https://doi.org/https://doi.org/10.15294/jscpe.v4i2

Arikunto, S. (2013). Prosedur Penelitian Suatu Pendekatan Praktik. Rineka Cipta.

Chéilleachair, N. J. N., Giles, A. J. H., \& Warrington, D. (2016). HIIT Enhances Endurance Performance And Aerobic Characteristics More Than High-Volume Training In Trained Rowers. Journal of Sports Sciencesica, 35(11), 1052-1058. https://doi.org/doi.org/10.1080/02640414.2016.1209539

Elamaran, M. (2014). Efficacy of Intensive and Extensive Interval Training On Selected Biomotor Abilities among Schoolboys. International Journal of Physical Education, Fitness and Sports, 3(1), 80-84. https://doi.org/10.26524/14114

Ginanjar, A. (2019). Metode Penelitian Kuantitatif dalam Pendidikan Jasmani dan Olahraga. Indramayu: Program Studi Pendidikan Jasmani, Kesehatan, dan Rekreasi STKIP Nahdlatul Ulama Indramayu. Program Studi Pendidikan Jasmani Kesehatan dan Rekreasi STKIP Nahdlaltul Ulama Indramayu.

Giriwijoyo, H. Y. S. S., \& Sidik, D. Z. (2012). IImu Faal Olahraga (Fisiologi Olahraga). PT. Remaja Rosdakarya.

Harsono. (2017). Kepelatihan Olahraga Teori dan Metodologi. PT Remaja Rosdakarya.

Harsono. (2018). Latihan Kondisi Fisik Untuk Atlet Sehat Dan Aktif. PT Remaja Rosdakarya.

Hebisz, R., Hebisz, P., Borkowski, J., \& Zatoń, M. (2016). Differences In Physiological Responses To Interval Training In Cyclists With And Without Interval Training Experience. Journal of Human Kinetics, 50(1), 93-101. https://doi.org/10.1515/hukin2015-0147 
Karimah, N. S., Ray, H. R. D., Mulyana, R. B., \& Pitriani, P. (2019). High Intensity Interval Training Method and The Flexibility Effects on Increasing VO2max and Lactate Threshold. 362(ACPES), 98-102. https://doi.org/10.2991/acpes-19.2019.22

Kharisma, Y., \& Mubarok, M. Z. (2020). Pengaruh Latihan Interval Dengan Latihan Fartlek Terhadap Peningkatan VO2Max Pemain Bola Vol. Biormatika: Jurnal IImiah Fakultas Keguruan Dan IImu Pendidikan, 6(2), 125-131. https://doi.org/10.35569/biormatika.v6i02.811

Mubarok, M. Z. (2019). Pengaruh Latihan Small Sided Games Mengunakan Metode Interval Terhadap Peningkatan Dribbling Pemain Sepakbola. Biormatika: Jurnal IImiah Fakultas Keguruan Dan IImu Pendidikan, 5(02), 144-149. https://doi.org/10.35569/biormatika.v5i02.513

Mubarok, M. Z. (2021). Teori Latihan Olahraga. Program Studi Pendidikan Jasmani Kesehatan dan Rekreasi STKIP Nahdlaltul Ulama Indramayu.

Mubarok, M. Z., \& Mudzakir, D. O. (2020). Pengaruh Latihan Small Sided Games Terhadap Peningkatan Keterampilan Dribbling Pemain Sepakbola. Jurnal Pendidikan Olahraga, 9(1), 28. https://doi.org/10.31571/jpo.v9i1.1381

Mubarok, M. Z., \& Ramadhan, R. (2019). Analisis Tingkat VO2Max Pemain Sepak Bola Darul Ma'arif Indramayu. Jurnal Kependidikan Jasmani Dan Olahraga, 3(1), 39-45. https://ejournal.stkipnu.ac.id/public_html/ejournal/index.php/jkjo/article/view/55

Mulyawan, R., Sidik, D. Z., \& Hidayat, N. (2016). Dampak Penerapan Pola Pelatihan Harness Menggunakan Metode Interval Dan Repetisi Terhadap Peningkatan Kemampuan Power Endurance Tungkai. Jurnal Sains Keolahragaan Dan Kesehatan, 1(1), 1. https://doi.org/10.5614/jskk.2016.1.1.1

Nurhasan, \& Cholil, D. H. (2012). Tes Dan Pengukuran Keolahragaan. FPOK UPI Bandung.

Rosdiana, F., Sidik, D. Z., \& Rusdiana, A. (2019). The Implementation Impact of High Intensity Interval Training (HIIT) Methods for the Increase of Anaerobic Abilities (Experimental study of physical training for 28 day meeting on student activity unit women futsal UPI Bandung). 11(ICSSHPE 2018), 17-19. https://doi.org/10.2991/icsshpe-18.2019.5

Sari, Y., Sidik, D. Z., \& Komarudin, K. (2019). The Application of High Intensity Interval Training (HIIT) Method to the Increase of Aerobic Ability of Female Futsal Players. 11(ICSSHPE 2018), 20-22. https://doi.org/10.2991/icsshpe-18.2019.6

Sidik, D. Z. (2011). Peningkatkan Kemampuan Anaerob \& Aerob Melalui Pelatihan Harness. Jurnal Kepelatihan Olahraga, 3(2), 35-45.

Sidik, D. Z., Pesurnay, P. L., \& Afari, L. (2019). Pelatihan Kondisi Fisik. PT. Remaja Rosdakarya. 
Mochamad Zakky Mubarok \& Yudhi Kharisma| Perbandingan Metode Latihan Interval Ekstensif dan Intensif Terhadap Peningkatan Daya Tahan Aerobik

Sugiyono. (2019). Metode Penelitian Kuantitatif, Kualitatif dan R\&D. Alfabeta.

Suhdy, M. (2018). Pengaruh Metode Latihan Interval Intensif dan Interval Ekstensif terhadap Peningkatan VO2 Max. Gelanggang Olahraga: Jurnal Pendidikan Jasmani Dan Olahraga (JPJO), 1(2), 1-10. https://doi.org/10.31539/jpjo.v1i2.130

Yamin, A., \& Gusril. (2020). Pengaruh Latihan Interval Intensif Dan Interval Ekstensif Terhadap Peningkatan Volume Oksigen Maksimal (Vo2 Max) Pemain Sekolah Sepak Bola Pengcab Mandailing Natal. Journal of Chemical Information and Modeling, 3(1), 17-30. https://doi.org/https://doi.org/10.24036/jst.v3i1.480 